International Journal of Engineering \& Technology, 7 (4) (2018) 2655-2662
International Journal of Engineering \& Technology
SPC
Website: www.sciencepubco.com/index.php/IJET
doi: $10.14419 /$ ijet.v7i4.10452
Research paper

\title{
Family support indices for substance abuser in Terengganu
}

\author{
Fazillah A ${ }^{.1}$, Juahir $\mathrm{H}^{1}$ *, Toriman $\mathrm{E}^{.2}$, Mohamad $\mathrm{N}^{3,4,5}$, Kamarudin M. K. A ${ }^{.1}$, Fairuz A ${ }^{6}$, Omar S. M. H. $\mathrm{S}^{4,6}$, Adi- \\ ana $\mathbf{G}^{1}$, Mohamad $\mathbf{M}^{7}$ \\ ${ }^{1}$ East Coast Environmental Research Institute, Universiti Sultan Zainal Abidin, Gong Badak Campus, 21300 Terengganu, Malaysia \\ ${ }^{2}$ School of Social Development and Environmental Studies, Faculty of Social Science and Humanities, Universiti Kebangsaan Malaysia, \\ 43600 Bangi, Selangor, Malaysia \\ ${ }^{3}$ Faculty of Medicine, Universiti Sultan Zainal Abidin, 20400 Kuala Terengganu, Terengganu Malaysia \\ ${ }^{4}$ Centre for research in Addiction \\ ${ }^{5}$ Institute for Community Health Development \\ ${ }^{6}$ Faculty of Islamic Contemporary Studies \\ ${ }^{7}$ Faculty of Economics and Management Sciences, Universiti Sultan Zainal Abidin, Gong Badak Campus, 21300 Terengganu, \\ Malaysia \\ *Corresponding authorE-mail: mahadzirahmd@unisza.edu.my, hafizanj@gmail.com
}

\begin{abstract}
Substance abuse has been a longstanding global issue. Efforts are continuing to find solutions. Family support is important and occurs in different forms. This study was designed to identify factors influencing family support and to relate them to the types of support given to help develop family support indices. Factors deemed to influence family support were identified and subjected to factor analysis to determine the association. A family support index was developed based on the four types of family support investigated. The scale categories ranging from very good to very poor as the indicator for the level of family support in the study area. Family support indices for the four types of support were high. The form of family support with the highest index score was 'instrumental support'. We concluded that substance abusers received good family support with the highest score recorded for instrumental support. The indices developed can help authorities obtain a comprehensive picture of support given and design programs to use optimally family support in the management of sub-stance abuse.
\end{abstract}

Keywords: Factor Analysis; Family Support; Index; Instrumental Support; Substance Abuse.

\section{Introduction}

Malaysia is a country that is rapidly expanding its mission to become a developed country by 2020 [1]. However, similar to the other countries in the world, Malaysia also faces the challenges of overcoming the problem of substance abuse [2]. Other study found that the substance abuse problems are associated with various social and health related problems [3], [4]. This was affecting the healthcare system in which a good healthcare system is important to improve the standard living of human being [5].

In general, the treatment for rehabilitation process of substance abuser involved pharmacology and psychosocial approaches. Some of the findings reported that most of the effective treatment for substance abusers is behavioural therapy and a few models had been developed for this purposes [6], [7]. Many studies had been done to overcome the substance abuse problems, realising that the closest group that are greatly affected by a person is a family. They were seen to have an important role in rehabilitation process for substance abuser. One of the most important aspects to be focused on is from a family aspects in which reported in previous study that family support plays an important role in rehabilitation process [8].

Researchers had sive a broad interpretation for a family concept, covering from larger family members to a single-family member. Generally, a basic family includes a mother, father and children. According to the definition given by Enrique et al. (2007), a fami- ly can be a group of people that held together by a birth, a marriage or adoption or by a common residence or close emotional attachments [9]. In this study, family was referred to be person who has blood connections to each other and currently staying with a substance abuser that are associated with this research, stay alive and has close connections with the substance abuser. The idea that family intervention may influence in a rehabilitation process for a substance abuser had getting more attentions in various research fields. A family has an important role in the treatment of the diseases, including substance abuse problems through their supports given to the substance abusers.

Family support is a continuing process that is happens in our daily life, either between the parents and their children or even between the siblings. There is no specific definition given for a family support, since the supports given by a family are very wide including the physical and emotional aspects. Previous study had pointed out that the family peers, social, cultural and economic aspects may influence the rehabilitation process for substance abuser [10]. A family support has many themes in the treatment approaches. Based on the literature, there are four supports had been identified which are emotional support, information support, instrumental support and social championship [11]. In line with another study had stated a few types of supports comprising emotional, instrumental and information and tangible support [12]. The strength of the family support given are much needed to ensure the effectiveness of the rehabilitation process [13]. 
Some findings reported that the effective treatments for rehabilitation process of substance abuser required supports from all parties involved [14]. Therefore, we emphasised on the family support perspective. The previous study had said that an active involvement of family support in rehabilitation process has better outcomes compared to those who do not have family support [15]. Besides, the loss of family support had caused troubles in the treatment of substance abuse [16]. With regard to the study objectives, the measurement of family support for substance abusers in the study area can describe the support given by family members. The development of a family support index for substance abusers is an attempt to measure the family support given in an easy way. Index development is vital to measure a problem by taking into account several important domains which have significant value to the cases. Many indices have been developed in social studies to measure and describe the situation. Therefore, the present study had proposed to identify the major factors that contribute to the family support, hence to develop family support indices in the area of the population.

\section{Methodology}

\subsection{Research design and sample collection}

This study was conducted in Terengganu (Figure 1), covering all of the district area using a set of questionnaires adapted from Farah Syazrah et al. (2016) [17]. Some questions were modified in order to suit with this study. 245 respondents from family members of substance abuser had participated in this study. A quantitative data through purposive sampling was used in this study in which the respondents had been selected by National Antidrug Agency (NADA) officers. The study is limited to Malay and male respondents (100\%). This instrument consists of two parts. Part A comprises of 13 items consisting of the respondent's profile (13 items). Whilst part B consists of 50 items for family support without taking into considerations on the hindrance of support part. Four forms of supports were acknowledged as dimensions that are comprised of emotional, instrumental, information and spiritual supports and each dimension has a number of sub dimensions. Each items were measured using Likert Scale and sorted in ascending order ranging from 1 (highly disagree) to 10 (highly agree). The questionnaires were read to the family members exactly as the same wording sequences and marked by the researchers due to some illiterate issues family members in understanding the questions among the family members. This is to ensure that respondents can respond exactly well similar to the questions in order to reduce the response's bias so that response bias can be controlled.

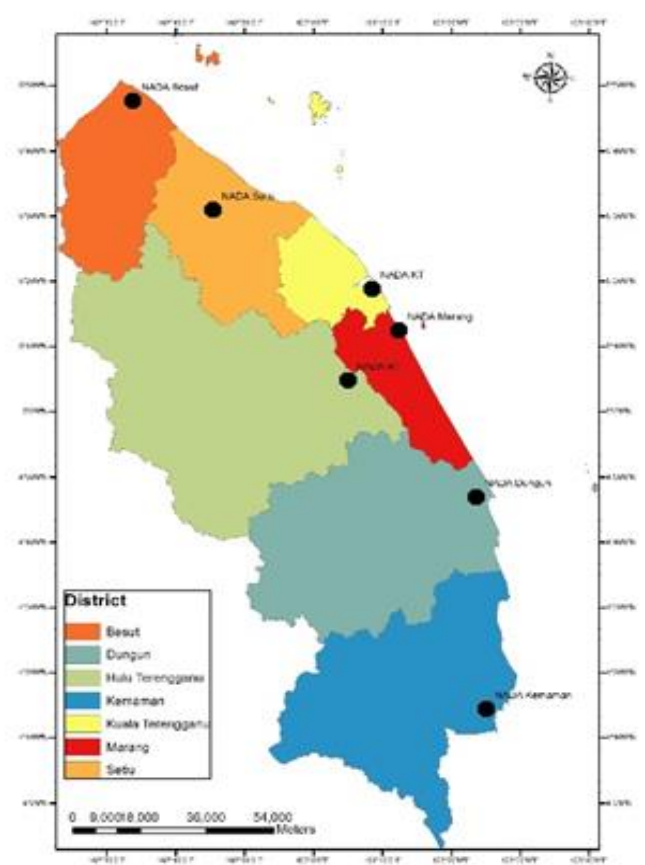

Fig. 1: Location of Seven Districts in the Study Area, Terengganu.

\subsection{Data analysis}

\subsubsection{Factor analysis}

Factor analysis (FA) is a method used to handle the abundance of a complex set of data and interpret it into a powerful means whereas it will analyses the data to generate a lower dimensional linear structure [18]. There are four forms of support to determine the family support used in this study. Factor analysis was applied in this study to identify the major factors that contribute to the family support. Besides, FA further develop into a family support indices. First, the suitability of the data set has to be checked by determining the Kaeiser- Mayer- Olkin (KMO) and Barlett's test values. For KMO values, the factor analysis can be proceed if the values are greater than 0.5 while the significant levels for Barlett test is less than 0.1 [19]. Then, varimax rotation was applied as a rotation method to produce a new orthogonal variable known as varifactors (VFs) based on the eigenvalues that is greater than 1 [20]. The VFs can be expressed as:

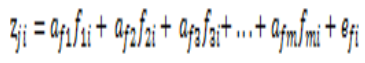

Where $\mathrm{z}$ is the measured value of a variable, $a$ is the factor loading, $f$ is the factor score, $e$ is the residual term accounting for errors or other sources of variation, $i$ is the samples number, $j$ is the variables number and $m$ is the total number of factors.

Each underlying dimensions are referred as factors and the factors explain the most variability in the data observed which factor 1 consider as the most variance following the next factors after that [21]. In this study, FA was applied to the data (four form of support) separately for seven district in Terengganu. Each form of support has different number of variable, where emotional support, instrumental support, information support and spiritual support have 14, 11, 13 and 12 variables respectively. Hence, each form of support index was developed by combining the factor scores generated by FA. The overall score for each respondent was obtained by weighing each factor score with the respective variance using the equation below:

$\mathrm{FS}_{\mathrm{i}}=\sum_{\mathrm{i}}^{\mathrm{n}} \mathrm{F}_{\mathrm{I}} \mathrm{w}_{\mathrm{i}}$

Where $\mathrm{FS}_{\mathrm{i}}$ is form of family support, $\mathrm{n}$ is the number of factors selected, $F_{i}$ is factor $i$ score and $\mathrm{W}_{\mathrm{I}}$ is the percentage of variance factor i explains. 


\section{Result}

\subsection{Socio demographic of respondents}

The socio demographic data of respondents was analysed using descriptive statistic. The results were presented at both individual and household level in order to understand the demography characteristics of family members of substance abusers. The analysis done for socio-demographic of respondents gives a view on the background of substance abusers (Figure 2). The mean and standard deviations shows age as the highest one compared the others. While, religion and nation has the lowest one due to the all respondents are Muslim.

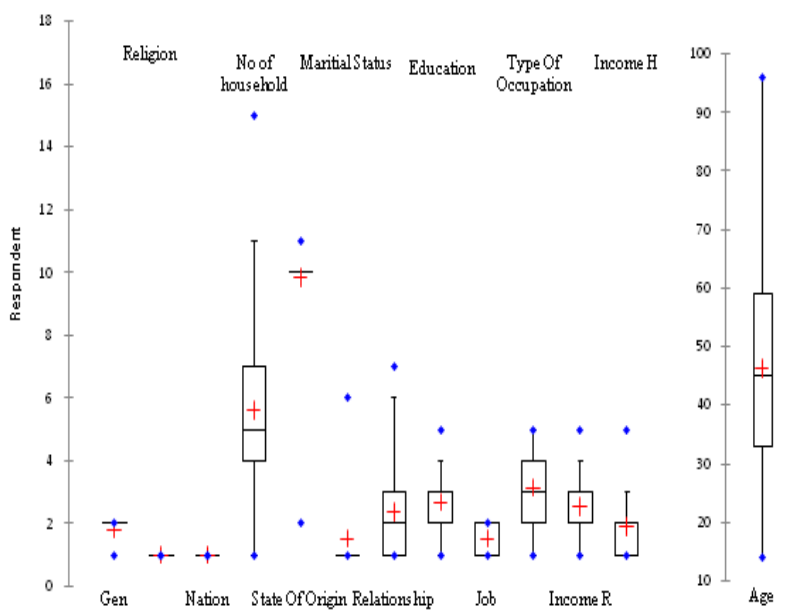

Fig. 2: Socio-Demographic Characteristic of Respondents.

*Number of observation: 245

\section{Discussion}

$52(21.22 \%)$ out of 245 respondents are males and $193(78.78 \%)$ are females. The respondents come from various states, which are mainly from Terengganu $89.39 \%$, Kelantan $3.27 \%$ and $2.86 \%$ Thailand. The other respondents are from Perak $(0.41 \%)$, Melaka $(0.41 \%)$, Johor $(1.22 \%)$ and Pahang $(0.82 \%)$. All respondents in this study are aged between 14 to 96 years old. Most of the respondents are 30 years old and above. Based on our analysis, socio demographic of respondents were low level indicating that the background of substance abuser came from low socio economic status. Several studies have proven that most of substance abusers come from low socio economic class. A research done by Reinherz et al. (2000) agreed that poor socio economic status and a big size of family might influence someone to become a substance abuser [22]. Another study has also shown that family background act as a primary factor to substance abuse [23].

\subsection{Factors contributing to family support}

In this study, we have analysed each form of family support provided to the substance abusers. Factor analysis was applied in this study due to the ability of this analysis to determine the variation of data set and to explore the hidden features of a complex data set [24]. Additionally, this analysis is able to identify the factors that has significant effect to the form of support, hence developing indices using several variables. In the beginning of this study, factor analysis was employed to understand and simplify the patterns of relationships underlying measured questions in a set of questionnaire for each form of support. Before the factor analysis was determined, the Keser-Meiyen-Olkin (KMO) and Barlett's test were performed according to each form of support to examine the suitability of the data set for factor analysis. The KMO value must be greater than 0.5 to measure the sampling adequacy that indicates the proportions of variance [19]. While Barlett's test must be less than 0.1 specifies whether correlation matrix in is an identity or not, which indicates the variable unrelated [25]. Consequently, all these form of support had their own value where are the KMO result for emotional support was 0.76 , instrumental support higher than $0.5(0.69)$, information support resulting the value of KMO was 0.79 and spiritual support, resulting 0.78 of KMO.

Factor analysis with factor loading and the proportion of variance accounted for emotional support is shown in table 1 . The loading value is referred to the measurement of associations between an item and factor [26] and it had classified factor loading into strong $(>0.75)$, moderate $(0.75-0.5)$ and weak $(0.5-0.3)$ [27]. In this study, the variables with factor loading value those are greater than 0.5 will be considered to identify the dimensions.

Table 1: Result of FA (Emotional Support) after Varimax Rotation

\begin{tabular}{llll}
\hline Variable & Acceptance & Attention & Involvement \\
\hline Attention 1 & 0.2734 & 0.6381 & 0.1775 \\
Attention 2 & 0.3503 & 0.5922 & 0.186 \\
Attention 3 & 0.123 & 0.174 & 0.9765 \\
Attention 4 & 0.4851 & 0.288 & 0.275 \\
Attention 5 & 0.7726 & 0.1829 & 0.1594 \\
Attention 6 & 0.8234 & 0.2247 & 0.2608 \\
Attention 7 & 0.5733 & 0.4075 & 0.3874 \\
Attention 8 & 0.1266 & -0.2068 & 0.0664 \\
Confidence 1 & -0.1345 & 0.2635 & -0.0389 \\
Confidence 2 & 0.3378 & 0.4671 & 0.1604 \\
Confidence 3 & -0.3305 & 0.4265 & 0.1025 \\
Confidence 4 & -0.3303 & 0.3324 & 0.1774 \\
Empathy 1 & 0.2608 & 0.0276 & 0.794 \\
Empathy 2 & 0.3791 & 0.7472 & 0.2134 \\
Eigenvalue & 4.688 & 1.217 & 1.1165 \\
Variability (\%) & 18.785 & 16.4484 & 14.9172 \\
Cumulative \% & 18.785 & 35.2334 & 50.1507 \\
\hline
\end{tabular}

*The bold one indicating high loading value.

In factor analysis, it is important to interpret the factor loading for each VFs in order to identify the meaning of VFs. Table 1 shows the emotional support gave $50.15 \%$ of cumulative variance and had yielded three factors such as below:

i) Factor 1: the acceptance was interpreted for factor 1, explains $18.79 \%$ of the variance. Since it shows high loading on attention part which showing the acceptance by respondents on substance abuser. The acceptance means that the respondents had gave full supports to the substance abuser to help them recover by giving praises and the endless love This is suggested that the higher the score in this factor, the higher the emotional support towards substance abuser to recover.

ii) Factor 2: the second factor was interpreted as attention since it shows high loading on attention 1 , attention 2 and empathy 2 which indicate the attention given by respondents on substance abuser with $16.45 \%$ of the variance. An attention is an indirect actions of family members towards the substance abuser's life. The higher the score in this factor donating positive enhancement in instrumental support by family members.

iii) Factor 3: the third factor was interpreted as involvement since it shows high positively loading on attention 3 and empathy 1 which indicating the involvement of respondents in substance abuser daily life. The higher the score in this factor, the higher emotional support given to substance abuser. This factor explains $14.92 \%$ from the total variance.

Table 2 clearly shows the actual questions that has high loading values and this findings are in line with the type of emotional support as proposed by Dennis et al. (2013), where the effectiveness of emotional support can be categorized into five types [28]. There are empathy, praises, advices, reassurances and encouragement to others. While Burleson et al. (2003) had quantified that emotional supports can be delivered via listening, emphasizing with and actively exploring their feelings [29]. Family involvements are also contribute also contributing to the emotional support given as given by previous study indicating the associations of family in- 
volvement are also contribute to the emotional support where the increase in family involvement results in increasing emotional support [30]. These factors were in concordance with the previous study. Most of the respondent reveals that larger household size give higher support [31]. whereas, perceptible most of respondents have big size family.

Table 2: Questions with Loading Factors for Emotional Support

\begin{tabular}{|c|c|c|}
\hline No. & $\begin{array}{l}\text { Variable with high } \\
\text { loading value }\end{array}$ & Actual Questions \\
\hline 1 & Attention 1 & I give attention to the substance abuser. \\
\hline 2 & Attention 2 & I accept the Substance abuser as he/she is. \\
\hline 3 & Attention 3 & $\begin{array}{l}\text { I help Substance abusers who are not keen to } \\
\text { recover. }\end{array}$ \\
\hline 4 & Attention 5 & $\begin{array}{l}\text { I praise the effort of the Substance abuser } \\
\text { for recovery. }\end{array}$ \\
\hline 5 & Attention 6 & $\begin{array}{l}\text { I convince the Substance abuser that he/she } \\
\text { is appreciated. }\end{array}$ \\
\hline 6 & Attention 7 & I give my care to the Substance abuser. \\
\hline 7 & Empathy 1 & $\begin{array}{l}\text { My relationship with the Substance abuser } \\
\text { remains close. }\end{array}$ \\
\hline 8 & Empathy 2 & $\begin{array}{l}\text { I effort to help the Substance abuser recover } \\
\text { together with his/her family members }\end{array}$ \\
\hline
\end{tabular}

Table 3 shows high loading factors for instrumental support indicates that the three VFs generated was the total variance $53.46 \%$ of the total variances in the data set of instrumental support, hence, Table 4 shows the actual questions in instrumental support with high loading value. The first factor explains $20.63 \%$ variances followed by $15.11 \%$ and $17.72 \%$ of variances for factor 2 and factor 3 respectively. Each factor interpreted as follows:

i) Factor 1: this factor has the highest variance value named as employment since it shows high positive loading on variable T\&E 3, T\&E 4 and T\&E 5. These three variables were positively correlated with the factor and it shows that the respondents had put an effort on helping the substance abuser to get a job. This implies that the higher the score in this factor, the higher the employable help from the family members for substance abusers in getting a job.

ii) Factor 2: the second factor consists of two variables that are social 1 and social 3 with positive loading values interpreted as social. This factor showed that the effort of respondents in engaging substance abuser with the public. This suggest the higher the score in this factor the higher the support of family members in community involvement with substance abuser.

iii) Factor 3: two variables (T\&E 1 and $T \& E$ 2) showed high positive loading in this factor. Both of them indicate the supports given to the substance abusers in helping them to have a skill from the training and hence getting a job. This factor can be interpreted as training and it is suggested that the higher the score in this factor, the higher the supports given in instrumental support.

Table 3: Result of FA (Instrumental Support) After Varimax Rotation

\begin{tabular}{llll}
\hline Variable & Employment & Social & Training \\
\hline T \& E 1 & 0.2046 & 0.0325 & 0.9718 \\
T \& E 2 & 0.23 & 0.0394 & 0.858 \\
T \& E 3 & 0.8179 & 0.1454 & 0.2807 \\
T \& E 4 & 0.8534 & 0.1115 & 0.2796 \\
T \& E 5 & 0.8294 & 0.025 & 0.0948 \\
T \& E 6 & 0.1828 & 0.3499 & 0.1161 \\
Social 1 & 0.1603 & 0.6643 & 0.0505 \\
Social 2 & 0.0931 & 0.4588 & 0.0555 \\
Social 3 & 0.0937 & 0.912 & 0.0363 \\
Financial 1 & 0.0465 & 0.0487 & 0.216 \\
Financial 2 & 0.104 & 0.1307 & 0.1885 \\
Eigenvalue & 3.3661 & 1.47 & 1.0448 \\
Variance $(\%)$ & 20.6307 & 15.1112 & 17.719 \\
Cumulative variance $(\%)$ & 20.6307 & 35.7419 & 53.4609 \\
\hline
\end{tabular}

*The bold one indicating high loading value.

The completely instrumental support in this study indicates three main factors that are contribute to the instrumental support given.
They are employable, social and training. A study carried out by Yim and Waters (2013) has found out that skills training and building a networking were associated with the instrumental support [32]. We believe that by involving the substance abusers to the community, it will help them to build a networking between them and the society. In the meantime, helping them to undergo the skills training also indirectly helping them to find a job. Analysis on this form of support indicates that most of them were from verbal help without giving money to the substance abusers. This is due to the low socio economic class among the respondents. Another study found out that although low socio economic class has poor connections to others, they still have a close bonding in giving the supports to their family members [33].

Two factors had been yielded for information support as shown in Table 5. Each VF has $30.99 \%$ and $17.20 \%$ from the total of variances respectively and interpreted as below:

i) Factor 1: according to the strong loading value in this group, all of them are from the information part, which is the parts of the information support. Based on the positive strong loading values generated, this factor was named as information where the higher score in this factor. Informations showed that respondents had put high efforts in getting information and share them with the substance abusers for their rehabilitation process. These informations were acquired via the efforts from the governments and NADA in implementing the appropriate programmes to disseminate the informations about the substance abusers with the aims to eradicate the substance abuse's problems [34]. Besides, the families of OKP also were invited to join few sessions with OKP in NADA.The higher information supports given by the family of substance abusers.

ii) Factor 2: strong loading value in this factor was from recommendation item. This factor can be interpreted as recommendation since high loading value in this factor given by recommendation item. The recommendation factor comprised of the advices and guidance from the respondents to substance abuser. The actual questions of instrumental support with high loading value as shown in Table 6. It is suggest that the higher the score in this factor the higher information support given to substance abuser. Figure 3 represents a detailed view of those strong loading values which approaching 1 .

Table 4: Questions with Loading Factors for Instrumental Support

\begin{tabular}{|c|c|c|}
\hline No. & $\begin{array}{l}\text { Variable with high } \\
\text { loading value }\end{array}$ & Actual Questions \\
\hline 1 & $\mathrm{~T} \& \mathrm{E} 1$ & $\begin{array}{l}\text { I help the Substance abuser to receive } \\
\text { skills training. }\end{array}$ \\
\hline 2 & $\mathrm{~T} \& \mathrm{E} 2$ & $\begin{array}{l}\text { I introduce agencies that provide training } \\
\text { to substance abusers. }\end{array}$ \\
\hline 3 & $\mathrm{~T} \& \mathrm{E} 3$ & I help the Substance abuser to get a job. \\
\hline 4 & $\mathrm{~T} \& \mathrm{E} 4$ & $\begin{array}{l}\text { I assure the Substance abuser of his/her } \\
\text { ability to get a job. }\end{array}$ \\
\hline 5 & $\mathrm{~T} \& \mathrm{E} 5$ & $\begin{array}{l}\text { I did not help the Substance abuser to get a } \\
\text { job. }\end{array}$ \\
\hline 6 & Social 1 & $\begin{array}{l}\text { I encourage the Substance abuser to mingle } \\
\text { around with the community. }\end{array}$ \\
\hline 7 & Social 3 & $\begin{array}{l}\text { I am a mediator between the Substance } \\
\text { abuser and the community. }\end{array}$ \\
\hline
\end{tabular}

Table 5: Result of FA (Information Support) After Varimax Rotation Variable Information 1

Information 2 Information 3

Information 4

Information 5

Recommendation 1

Recommendation 2

Recommendation 3

Recommendation 4

Reference 1

Reference 2

Reference 3

\begin{tabular}{ll} 
Information & Recommendation \\
\hline 0.8945 & 0.0679 \\
0.918 & 0.0346 \\
0.878 & 0.2376 \\
0.8199 & 0.2769 \\
0.6818 & 0.1876 \\
0.1828 & 0.5944 \\
0.2814 & 0.6142 \\
0.1835 & 0.716 \\
0.1497 & 0.7641 \\
0.1863 & 0.0177 \\
0.4436 & 0.0523 \\
0.0961 & 0.1415
\end{tabular}




\begin{tabular}{lll}
\hline Reference 4 & 0.2628 & 0.4866 \\
Eigenvalue & 4.7599 & 1.5304 \\
Variance (\%) & 30.9947 & 17.3925 \\
Cumulative Variance (\%) & 30.9947 & 48.3873 \\
\hline
\end{tabular}

*The bold one indicating high loading value.

The variance for the two VFs yielded from FA to the spiritual support explaining $25.60 \%$ and $14.38 \%$ from the total of variances respectively (Table 7). Result shows loading values for each VFs and for a better understanding, each VFs was renamed according to the strong loading values for each VF list as below:

i) Factor one: this factor named as clarification since it shows a strong positive loading in the combination of clarification and the awareness items. It is suggested that the higher the score in this factor the higher spiritual supports given to the substance abusers.

ii) Factor two: as this factor has moderate positive loading in comprehension items, it can be interpreted as comprehension where the respondents tried to help the substance abusers to be more understanding about religion. Higher comprehension will contribute to the higher form of spiritual supports.

Table 6: Questions with Loading Factors for Information Support

\begin{tabular}{lll}
\hline No. & $\begin{array}{l}\text { Variable with high } \\
\text { loading value }\end{array}$ & Actual Questions \\
\hline 1 & Information 1 & $\begin{array}{l}\text { I try to find information about the rehabili- } \\
\text { tation of the Substance abuser. } \\
\text { I follow up with information regarding the } \\
\text { rehabilitation of the Substance abuser } \\
\text { I share information about substance rehabil- } \\
\text { itation with the Substance abuser. }\end{array}$ \\
3 & Information 2 & $\begin{array}{l}\text { I discuss the rehabilitation information of } \\
\text { the Substance abuser. }\end{array}$ \\
5 & Information 4 & $\begin{array}{l}\text { I do not effort to find information related to } \\
\text { substance rehabilitation. }\end{array}$ \\
6 & Recommendation 1 & $\begin{array}{l}\text { I explained how to manage daily life. } \\
\text { I bring the Substance abuser closer to reli- } \\
\text { gious institutions. } \\
\text { I advise the Substance abuser to stop their } \\
\text { addiction. }\end{array}$ \\
9 & Recommendation 2 & $\begin{array}{l}\text { I always give advice to the Substance abus- } \\
\text { er. }\end{array}$ \\
\hline
\end{tabular}

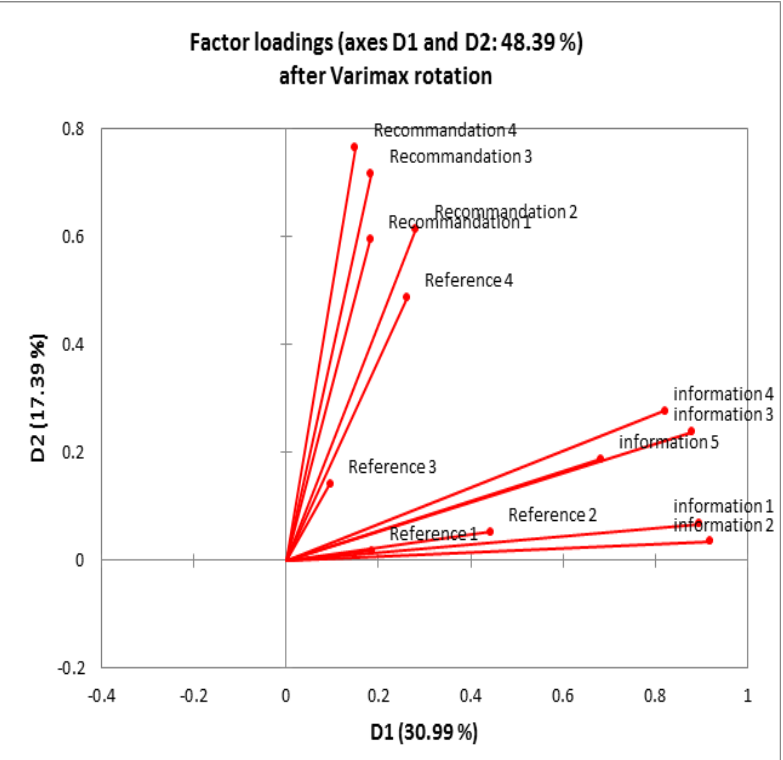

Fig. 3: Questions, which Have a High Tendency to Approach, Value 1.

Table 7: Result of FA (Spiritual Support) after Varimax Rotation

\begin{tabular}{lll}
\hline Variable & Clarification & Comprehension \\
\hline Comprehension 1 & 0.4953 & 0.5119 \\
Comprehension 2 & 0.0324 & 0.6116 \\
Comprehension 3 & 0.2017 & 0.5958 \\
Clarification 1 & 0.6671 & 0.1187 \\
Clarification 2 & 0.1946 & 0.3038 \\
\hline
\end{tabular}

\begin{tabular}{lll} 
Clarification 3 & 0.8261 & 0.2125 \\
Clarification 4 & 0.8266 & 0.1666 \\
Clarification 5 & 0.4114 & 0.1562 \\
Awareness 1 & 0.5165 & -0.2621 \\
Awareness 2 & 0.2393 & 0.1043 \\
Awareness 3 & 0.5794 & 0.1399 \\
Eigenvalue & 3.6852 & 1.113 \\
Variability (\%) & 25.6035 & 14.3808 \\
Cumulative \% & 25.6035 & 39.9843 \\
\hline
\end{tabular}

*The bold one indicating high loading value.

Table 8 shows the actual questions of spiritual support with high loading value. Two main factors contribute to the spiritual support namely the clarification and comprehension aspects. Since religion had been poorly discussed to be as form of support, this study is trying to bring forward the religion as one of the form of support because almost people in this world are adhere some religions [35] The religion here means Islam as it is associated with all of the respondents here that are Muslims. Krause et al. (2001) stated that there is a correlation between the social ties and the faith, which is essential in a religion an individual [36]. As can be seen, the families did not neglect the spiritual aspect and it was comprehensive given because the religious knowledge were organized since Malaysia is an Islamic country [37].

Table 8: Questions with Loading Factors for Spiritual Support

\begin{tabular}{|c|c|c|}
\hline No. & $\begin{array}{l}\text { Variable with high } \\
\text { loading value }\end{array}$ & Actual Questions \\
\hline 1 & Comprehension 1 & $\begin{array}{l}\text { I make sure the Substance abuser seeks for } \\
\text { knowledge about religion. }\end{array}$ \\
\hline 2 & Comprehension 2 & $\begin{array}{l}\text { I know the Substance abuser fully accepts } \\
\text { (redha) when Allah tests him/her with hard- } \\
\text { ship. }\end{array}$ \\
\hline 3 & Comprehension 3 & $\begin{array}{l}\text { I know the Substance abuser always attempts } \\
\text { to be closer to Allah. }\end{array}$ \\
\hline 4 & Comprehension 4 & $\begin{array}{l}\text { I make sure the Substance abuser attends } \\
\text { talks about religion. }\end{array}$ \\
\hline 5 & Clarification 1 & $\begin{array}{l}\text { I make sure the Substance abuser fasts in the } \\
\text { month of Ramadhan. }\end{array}$ \\
\hline 6 & Clarification 3 & $\begin{array}{l}\text { I make sure the Substance abuser works for a } \\
\text { halal livelihood. }\end{array}$ \\
\hline 7 & Clarification 4 & I explained that all deeds will be requited. \\
\hline 8 & Awareness 1 & $\begin{array}{l}\text { I pray that the Substance abuser returns to } \\
\text { the rightful path. }\end{array}$ \\
\hline 9 & Awareness 3 & $\begin{array}{l}\text { I make sure Islam is practiced in the Sub- } \\
\text { stance abuser's daily life. }\end{array}$ \\
\hline
\end{tabular}

\subsection{Developing family support indices}

Apart from determining the variations of the data set, FA was used to develop an index for family support. Developing an index for family support in this study was applied based on the method proposed by Li and Weng (2007) in their study on Quality of Life (QoL) [21]. There is no significant method to integrate the social indicator as a one single index. This is because there is no criteria to measure the weighted for this indicator. Nevertheless, we decided to apply a pragmatic solution for this case and assign factor score as indicator and associated the variance as weights [38]. Using the factor scores generated through factor analysis then weighting the respective variance of the factor score, the overall score for each respondent will be gained. The score will be transformed to the scale from 1 to 5 via minimum-maximum standardization technique to have similar range of the family support index value. The score of each form of support were arranged according to the hierarchy and the scale was determined from very good (1) to very poor (5) based on the frequency table as shown in Table 9. This score also can be used as family support index. Hence, all of the variables for emotional support, instrumental support, information support and spiritual support has been studied to develop family support indices in this study. Emotional support index and instrumental support index were computed by combining the scores of the three selected factors that are related to the dimension of those support respectively. As a result, the score calculated for emotional support in the study area ranging from -1.29 to 0.16 , 
while instrumental support produce the score in the ranged of 0.97 to 0.32 . Information support and spiritual support indices had been developed based on the combinations of two generated factors respectively, whereas information support indices has the scale ranging from -1.32 to 0.28 and spiritual support has the large variation scale in the range of -1.51 to 0.13 . The index developed for hindrance of the support then computed by combining the four selected factors resulting the range values of -1.99 to 0.00

Table 9: Frequency Table of Family Support Score

\begin{tabular}{|c|c|c|c|c|c|}
\hline Family Support Score & Freq. & Cum. Freq. & $\%$ & Cum. \% & Scale \\
\hline \multicolumn{6}{|l|}{ Emotional Support } \\
\hline-1.28912 & 3 & 3 & $1.22 \%$ & $1.22 \%$ & Very poor \\
\hline-0.92736 & 9 & 12 & $3.67 \%$ & $4.90 \%$ & poor \\
\hline-0.20385 & 145 & 181 & $59.18 \%$ & $73.88 \%$ & Good \\
\hline 0.157909 & 64 & 245 & $26.12 \%$ & $100.00 \%$ & Very good \\
\hline \multicolumn{6}{|l|}{ Instrumental Support } \\
\hline-0.96731 & 6 & 6 & $2.45 \%$ & $2.45 \%$ & Very Poor \\
\hline-0.64484 & 39 & 45 & $15.92 \%$ & $18.37 \%$ & Poor \\
\hline-0.32236 & 72 & 117 & $29.39 \%$ & $47.76 \%$ & Fair \\
\hline 0.000113 & 94 & 211 & $38.37 \%$ & $86.12 \%$ & Good \\
\hline 0.322589 & 34 & 245 & $13.88 \%$ & $100.00 \%$ & Very good \\
\hline \multicolumn{6}{|l|}{ Information Support } \\
\hline-1.32408 & 2 & 2 & $0.82 \%$ & $0.82 \%$ & Very Poor \\
\hline-0.92318 & 25 & 27 & $10.20 \%$ & $11.02 \%$ & Poor \\
\hline-0.52227 & 47 & 74 & $19.18 \%$ & $30.20 \%$ & Fair \\
\hline-0.12137 & 128 & 202 & $52.24 \%$ & $82.45 \%$ & Good \\
\hline \multicolumn{6}{|l|}{ Spiritual Support } \\
\hline-1.51419 & 1 & 1 & $0.41 \%$ & $0.41 \%$ & Very Poor \\
\hline-1.10291 & 11 & 12 & $4.49 \%$ & $4.90 \%$ & Poor \\
\hline-0.69163 & 11 & 23 & $4.49 \%$ & $9.39 \%$ & Fair \\
\hline-0.28035 & 162 & 185 & $66.12 \%$ & $75.51 \%$ & Good \\
\hline 0.130937 & 60 & 245 & $24.49 \%$ & $100.00 \%$ & Very good \\
\hline
\end{tabular}

According to the indices, developed, instrumental support has the highest index with the least scale of index compare to the other form of support indicating the most forms of supports given were through this support. Previous study had investigates that instrumental support involves practical assistance and material goods are more desired from the family members compared to the other people [39]. The family support measured in each district was based on the answer given by the respondents, as they have different perspectives from each form of support. Then, we determine the mean score for every district to get the whole picture of family support in the study area. Therefore, we will further discuss the form of family support by districts and examine the view of the respondents in that particular district. Hence, we applied GIS to visualise a clear picture of family support indices distributions in Terengganu (Figure 4 and 5).Based on figure 4, the darkest colour indicates the highest level of family support, meanwhile, the light colour represents the least level of family support. Besut had been identified as the highest emotional support district and Marang was the lowest one (Figure 2a). Besut is located in the north of Terengganu that is far from the main state. The main occupation of their residence is self-dependence and most of them are not working. It can be considered as low socio economic class and can be counted a reason why emotional support given by family members as the highest one. The high bonding between family members can contribute a successful emotional support delivery [33]. Low socio economic class families had spent more time with their family and close tie because most of them do not bond to office hour. This is contradict with the study by Salonna et al. (2012) in their literature stated that there are positive correlation between high socio economic class with social support [40].

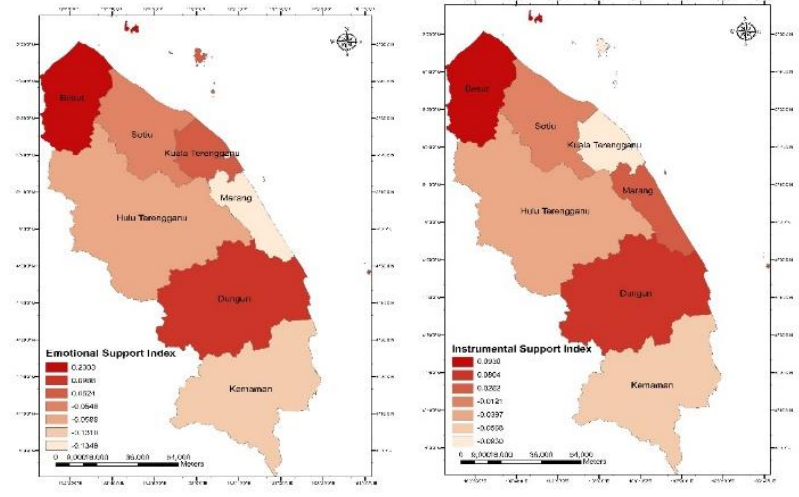

Fig. 4: Family Support Indices Map A) Emotional Support, B) Instrumental Support.

Similar to the emotional support, the highest instrumental support given was from Besut (Figure 4b). Our study found that this district indicating family gave more attention to their substance abuser with giving good instrumental support to substance abuser. Even though instrumental support involves the provision of material good, our finding showing that the major factor contributing to instrumental support here was not based on financial aspect due to their low socio-economic status, but in the form of employable help, community involvement and training aid which relating to practical assistance. In contrast, Weyers et al. (2008) and Melchiorre et al. (2013) documented that low socio economic people lack of social and instrumental support [33], [31].

Based on the map in Figure 5(a), the highest information support index in Terengganu was Setiu, followed by Dungun, Besut, Marang, Kuala Terengganu, Hulu Terengganu and Kemaman. Based on our study, Setiu is the smallest district in Terengganu with low substance abuser making them easily handle the cases and deliver information to family on managing substance abuser.

Figure $5 \mathrm{~b}$ shows the distribution map of spiritual support indices was highest in Besut followed by Dungun, Marang, Kuala Terengganu, Hulu Terengganu, Setiu and Kemaman accordingly. Kemaman was known as industrial area, which a lot of foreign worker acquired in that field. Social networking and different culture among foreign workers and local residence cause slightly 
influencing their religious strength. Previous study documented that culture may influenced by religion or inversely [41], [42].

The distribution map (Figure 4 and 5) represents that each district has different family supports in which their individual approach pretty varies. Labelling a district as high family support does not necessarily that every respondent in that district has same level of family support. The variation of family support given not only based on socio-demographic, but environmental surrounding as well [43]. The distribution of each support showing similar pattern for Besut, Hulu Terengganu and Dungun in term of giving all those support whereas, Besut and Dungun had high family support in contrast to Hulu Terengganu, which had lower family support. This is due to the location of Besut and Dungun bordering to other state in Peninsular Malaysia, which the society closer influencing them on giving support [44].

Nevertheless, Hulu Terengganu presented lower forms of family supports even though located adjacent to the other state. This might happen due to the characteristics of Hulu Terengganu itself. Even though the district is the biggest in Terengganu, most of the land used there is covered by reserve forest [45]. The population density in this district was also lowest denoted by the long distances among the residence's houses rendered less social bonding among the residences and low exposure to the substance abuse problems. The previous studies had shown that the social relationships might affect the individual's surroundings [46]. The social relationship is capable to make a person to be more open-minded and sharing knowledge on something thus reflect the positive affect to somebody.

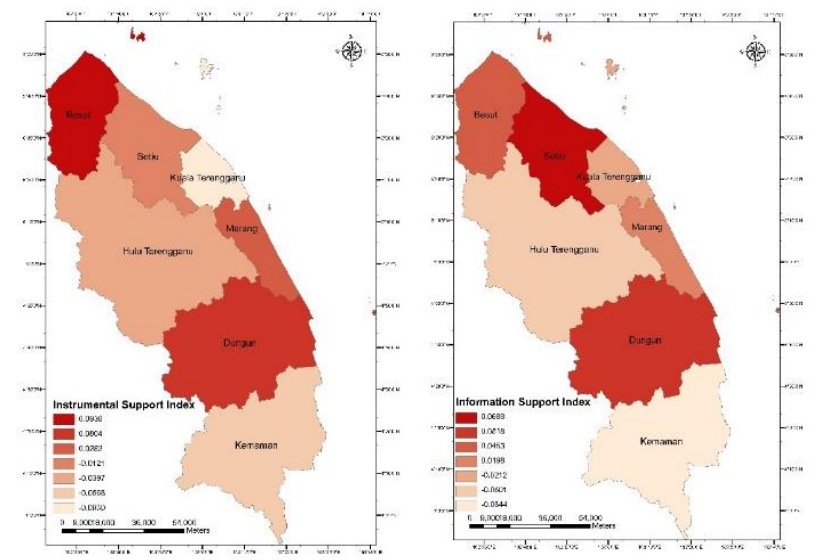

Fig. 5: Family Support Indices Map A) Information Support, B) Spiritual Suppor.

\section{Conclusion}

Developing indices for each form of family support showed the extent of support provided by family. We identified the family support given in each district are very well even though the support given quite varies for each form of support. The present study concluded the highest family support given in the study area is the instrumental support. The socio economic factors indicated the overall participants had low socio economic level which influencing the support given. The importance of GIS in this study is to visualise the distribution of family support indices via distribution maps. Through the distribution maps, the location of the district is one of the factors resulting the family support indices are different. Despite some limitation, this study provides a good overview on the family support given, thus assist the stakeholder involved to overcome the problems.

\section{Acknowledgement}

The authors would like to thank the Niche Research Grant Scheme (NRGS-KPM) UniSZA/NRGS/2013/RR057 for the research grant. A special thanks goes to the Ministry of Higher Education Malay- sia, Prison Department of Malaysia (Marang) and UniSZA for providing general assistance to this research. Finally and most importantly, we are greatly thankful to the East Coast Environmental Research Institute (ESERI) for their kind assistance in data analysis techniques and peer support in completing this paper.

\section{References}

[1] Mohamad, M., Ali, A. M., Ab Ghani, N. I., Abdullah, A. R., \& Mokhlis, S. 2013. Positioning Malaysia as a tourist destination based on destination loyalty. Asian Social Science. 9(1): 286-292. https://doi.org/10.5539/ass.v9n1p286.

[2] Kuldas, S., Hashim, S., and Ismail, H. N. 2014. Malaysian adolescent students' needs for enhancing thinking skills, counteracting risk factors and demonstrating academic resilience. International Journal of Adolescence and Youth. 20(1): 32-47. https://doi.org/10.1080/02673843.2014.973890.

[3] Mohamad, M., Mohammad, M., Mamat, I., and Mamat, M. 2014. Modelling positive development, life satisfaction and problem behaviour among youths in Malaysia. World Applied Sciences Journal. 32(2): 231-238. 10.5829/idosi.wasj.2014.32.02.14486

[4] De Maeyer, J., Vanderplasschen, W., Lammertyn, J., Van Nieuwenhuizen, C., Sabbe, B., and Broekaert, E. 2011. Current quality of life and its determinants among opiate-dependent individuals five years after starting methadone treatment. Quality of Life Research. $20 \quad 139-150$. 10.1007/s11136-010-9732-3 https://doi.org/10.1007/s11136-010-9732-3.

[5] Muhammad Kashif, Siti Zakiah Melatu Samsi and Zainudin Awang, M. M. 2016. International Journal of Pharmaceutical and Healthcare Marketing. International Journal of Pharmaceutical and Healthcare $\quad$ Marketing. $10(1)$ : 27-47. https://doi.org/10.1108/17506121211216905.

[6] Carroll, K. M., and Onken, L. S. 2005. Behavioral Therapies for Drug Abuse. Am J Psychiatry. (162): 1452-1460. https://doi.org/10.1176/appi.ajp.162.8.1452.

[7] Williams, R. J., and Chang, S. Y. 2000. A comprehensive and comparative review of adolescent substance abuse treatment outcome. Clinical Psychology: Science and Practice. 7 138-166. https://doi.org/10.1093/clipsy.7.2.138.

[8] Klostermann, K., and O'Farrell, T. J. 2013. Treating substance abuse: partner and family approaches. Social Work in Public Health. 28 (3-4): 234-247. https://doi.org/10.1080/19371918.2013.759014.

[9] Enrique, J. Howk, H. and Huitt, W. 2007. An overview of family development. Educational Psychology Interactive. Valdosta: Valdosta State University. Retrieved from http://www.edpsycinteractive.org/papers/family.pdf

[10] Embleton, L., Atwoli, L., Ayuku, D., and Braitstein, P. 2013. The Journey of Addiction: Barriers to and Facilitators of Drug Use Cessation among Street Children and Youths in Western Kenya. PLoS 1. 8(1): e53435. https://doi.org/10.1371/journal.pone.0053435.

[11] Toner, P., and Velleman, R. 2014. Initial reliability and validity of a new measure of perceived social support for family members of problem substance users. Addiction Research \& Theory. 22(2): 147-157. https://doi.org/10.3109/16066359.2013.779675.

[12] Schulz, U., and Schwarzer, R. 2004. Long-term effects of spousal support on coping with cancer after surgery. Journal of Social and Clinical Psychology. 23(5): 716-732. https://doi.org/10.1521/jscp.23.5.716.50746.

[13] Ibrahim, F., and Kumar, N. 2009. Factors Effecting Drug Relapse in Malaysia: An Empirical Evidence. Asian Social Science. 5 (12): 37-44. https://doi.org/10.5539/ass.v5n12p37.

[14] Rusdi A.R, Noor Zurani M.H.R, Muhammad M.A.Z and Mohamad, M. H. 2008. A fifty-year challenge in managing drug addiction in Malaysia. JUMMEC. 11(1): 3-6. https://doi.org/10.22452/jummec.vol11 1no1.2.

[15] Foster, A. M., Armstrong, J., Buckley, A., Sherry, J., Young, T., Foliaki, S., James-Hohaia, Te M., Theadom, A., and McPherson, K M. 2012. Encouraging family engagement in the rehabilitation process: a rehabilitation provider's development of support strategies for family members of people with traumatic brain injury. Disability and Rehabilitation. 34 (22): 1855-1862. https://doi.org/10.3109/09638288.2012.670028

[16] Chie, Q. T., Tam, C. L., Bonn, G., Wong, C. P., Dang, H. M., and Khairuddin, R. 2015. Drug abuse, relapse, and prevention education in Malaysia: perspective of university students through a mixed methods approach. Frontiers in Psychiatry. 6, 65. https://doi.org/10.3389/fpsyt.2015.00065. 
[17] Farah Syazrah Mohd Ghazali, Siti Nor Fazillah binti Abdullah, Hafizan Juahir, Norizan Abdul Ghani, Mohamad Azizi Amran and Mohd Ekhwan Toriman. (2016, 8- 10 Oktober). Assessment by multivariate analysis of family social support towards opiate dependent: A vase study in Besut. Paper presented at the International Postgraduate Research Conference retrieved Oktober 30, 2016 from www.unisza.edu.my/iprc2016/

[18] Singh, K. P., Malik, A., and Sinha, S. 2005. Water quality assessment and apportionment of pollution sources of Gomti river (India) using multivariate statistical techniques-a case study. Analytica $\begin{array}{lll}\text { Chimica } & \text { Acta. } & \text { 538: }\end{array}$ https://doi.org/10.1016/j.aca.2005.02.006 ...

[19] Wu, M.-L., Wang, Y.-S., Sun, C.-C., Wang, H., Dong, J.-D., Yin, J.-P., and Han, S.-H. 2010. Identification of coastal water quality by statistical analysis methods in Daya Bay, South China Sea. Marine Pollution Bulletin. 60(6): 852-860. https://doi.org/10.1016/j.marpolbul.2010.01.007.

[20] Wang, Y., Wang, P., Bai, Y., Tian, Z., Li, J., Shao, X., Mustavich, L. F., and Li, B.-L. 2013. Assessment of surface water quality via multivariate statistical techniques: A case study of the Songhua River Harbin region, China. Journal of Hydro-Environment Research. 7: 30-40. https://doi.org/10.1016/j.jher.2012.10.003.

[21] Li, G., and Weng, Q. 2007. Measuring the quality of life in city of Indianapolis by integration of remote sensing and census data. International Journal of Remote Sensing. 28(2): 249-267. https://doi.org/10.1080/01431160600735624.

[22] Reinherz, H. Z., Giaconia, R. M., Hauf, A. M. C., Wasserman, M S., and Paradis, A. D. 2000. General and Specific Childhood Risk Factors for Depression and Drug Disorders by Early Adulthood. Journal of the American Academy of Child and Adolescent Psychiatry. 39(2): 223-231. https://doi.org/10.1097/00004583200002000-00023.

[23] Lian, T. C., and Chu, F. Y. 2013. A Qualitative Study on Drug Abuse Relapse in Malaysia: Contributory Factors and Treatment Effectiveness. International Journal of Collaborative Research on Internal Medicine and Public Health. 5(4): 217-232.

[24] Li, S., Li, J., and Zhang, Q. 2011. Water quality assessment in the rivers along the water conveyance system of the Middle Route of the South to North Water Transfer Project (China) using multivariate statistical techniques and receptor modeling. Journal of Hazardous Materials.195 306-317. https://doi.org/10.1016/j.jhazmat.2011.08.043.

[25] Lin, C. Y., Abdullah, M. H., Praveena, S. M., Yahaya, A. H. B., and Musta, B. 2012. Delineation of temporal variability and governing factors influencing the spatial variability of shallow groundwater chemistry in a tropical sedimentary island. Journal of Hydrology. 432-433: https://doi.org/10.1016/j.jhydrol.2012.02.015

[26] Bryman, A., and Cramer, D. 2011. Quantitative Data Analysis with IBM SPSS 17, 18 and 19. A Guide for Social Scientists. New York Routledge.

[27] Liu, C., Lin, K., and Kuo, Y. 2003. Application of factor analysis in the assessment of groundwater quality in a blackfoot disease area in Taiwan. The Science of the Total Environment.313 77-89. http://doi.org/10.1016/S0048-9697 (02)00683-6

[28] Dennis, M., Masthoff, J., and Mellish, C. 2013. Does learner conscientiousness matter when generating emotional support in feedback? In proceedings-2013 Humaine Association Conference on Affective Computing and Intelligent Interaction, ACII 2013 (pp. 209-214). [6681432]

[29] Burleson, B. R. 2003. The experience and effects of emotional support: What the study of cultural and gender differences can tell us about close relationships, emotion, and interpersonal communication. Personal Relationships.10 1-23. https://doi.org/10.1111/14756811.00033 .

[30] Adams, G. A., King, L. A., and King, D. W. (1996). Relationships of job and family involvement, family social support, and workfamily conflict with job and life satisfaction. Journal of Applied Psychology. 81(4): 411-420. https://doi.org/10.1037/0021 9010.81.4.411.

[31] Melchiorre, M. G., Chiatti, C., Lamura, G., Torres-Gonzales, F., Stankunas, M., Lindert, J., Ioannidi-Kapolou, E., Barros, H., Macassa, G., and Soares, J. F. J. 2013. Social Support, SocioEconomic Status, Health and Abuse among Older People in Seven European Countries. PLoS 1. 8(1): e54856. https://doi.org/10.1371/journal.pone.0054856.

[32] Yim, L., and Waters, L. 2013. The Role of Interpersonal Comfort, Attributional Confidence, and Communication Quality in Academic Mentoring Relationships. Education Research and Perspectives. 40: $58-85$.
[33] Weyers, S., Dragano, N., Möbus, S., Beck, E.-M., Stang, A., Möhlenkamp, S., Jockel, K. H., Erbel, R., and Siegrist, J. 2008. Low socio-economic position is associated with poor social networks and social support: results from the Heinz Nixdorf Recall Study. International Journal of Equity in Health. 7(13). https://doi.org/10.1186/1475-9276-7-13.

[34] Al Sayed Mohamad, S. M. A., Mohamad, Z., Ismail, B., and Yusof, R. A. @ R. M. 2013. Therapeutic Experience of Drug Rehabilitation Clients through Expressive Arts Therapy. International Journal of Humanities and Social Science.3 (17): 210-223.

[35] Thagard, P. 2005. The Emotional Coherence of Religion. Journal of $\begin{array}{lll}\text { Cognition } & \text { Culture. } & \\ \end{array}$ https://doi.org/10.1163/1568537054068642.

[36] Krause, N., Ellison, C. G., Shaw, B. A., Marcum, J. P., and Boardman, J. D. 2001. Church-Based Social Support and Religious Coping. Journal for the Scientific Study of Religion. 40(4): 637-656. https://doi.org/10.1111/0021-8294.00082.

[37] Singh, D., Marek C. Chawarski, Richard Schottenfeld, and B. V. 2013. Substance abuse and the HIV situation in Malaysia. J Food Drug Anal. 21(4): https://doi.org/10.1016/j.jfda.2013.09.033

[38] Schyns, P., and Boelhouwer, J. 2004. The state of the city Amsterdam monitor: Measuring Quality of Life in Amsterdam. In Sirgy, M. J., Rahtz, D., and Lee, D-J., Community quality of life indicators (pp. 133-152), Springer Netherlands. https://doi.org/10.1007/978-1-4020-2202-9_6.

[39] Helgeson, V. S., and Cohen, S. 1996. Social support and adjustment to cancer: reconciling descriptive, correlational, and intervention research. Health Psychology. 15(2): 135-148 https://doi.org/10.1037/0278-6133.15.2.135

[40] Salonna, F., Geckova, A. M., Zezula, I., Sleskova, M., Groothoff, J. W., Reijneveld, S. A., and Van Dijk, J. P. 2012. Does social support mediate or moderate socioeconomic differences in self-rated health among adolescents? International Journal of Public Health.57: 609 617. https://doi.org/10.1007/s00038-011-0300-6.

[41] Raday, F. 2003. Culture, Religion, and Gender. International Journal of Constitutional Law. 1(4): 663-715. https://doi.org/10.1093/icon/1.4.663.

[42] Bonney, R. 2004. Reflections on the differences between religion and culture. Clinical Cornerstone. 6(1): 25-33. http://doi.org/10.1016/S1098-3597 (04)90004-X

[43] Hicks, B. M., Foster, K. T., Iacono, W. G., and McGue, M. 2013. Genetic and environmental influences on the familial transmission of externalizing disorders in adoptive and twin offspring. JAMA Psychiatry.70 (10): https://doi.org/10.1001/jamapsychiatry.2013.258.

[44] Uchino, B. N. 2005. Social Support and Physical Health: Understanding the Health Consequences of Relationships. American Journal of Epidemiology.161 297-298 https://doi.org/10.1093/aje/kwi036.

[45] Department of Statistic Malaysia. 2015. Population and Housing Census Report of Malaysia. (2010). Retrieved from https://www.dosm.gov.my/v1/index.php?r=column/cthemeByCatan dcat=117\&bul_id=MDMxdHZjWTk1SjFzTzNkRXYzcVZjdz09\& menu_id=L0pheU43NWJwRWVSZk1WdzQ4TlhUUT09

[46] Nurullah, A. S. 2012. Received and provided social support: A review of current evidence and future directions. American Journal of Health Studies. 27(3): 173-188. Retrieved from http://works.bepress.com/nurullah/3/ Patient Education and Counseling $53,309-313$. 